\title{
Disentangling the effects of ontogeny and environmental factors on xylem anatomy in a semiarid chamaephyte
}

\author{
Eugenio, M. ${ }^{\mathrm{a}, *}$, Olano, J.M. ${ }^{\mathrm{a}}$, Fonti, $^{\mathrm{b}} .^{\mathrm{b}}$ \\ a Área de Botánica, Departamento de Ciencias Agroforestales, EU de Ingenierías Agrarias, Universidad de Valladolid, Campus \\ Duques de Soria. E-42004 Soria, Spain \\ ${ }^{\mathrm{b}}$ Swiss Federal Research Institute WSL, Dendro Sciences Unit, Zürcherstrasse 111, CH-8903 Birmensdorf, Switzerland \\ * Corresponding author: Màrcia Eugenio Gosalbo. Present address: Área de Botánica, Departamento de Ciencias Agroforestales, EU \\ de Ingenierías Agrarias, UVa, Campus Los Pajaritos s/n, Soria 42004, Spain. Tel.: +34 97512 94 84; fax: +34 975129471 - E-mail \\ address: m.eugenio@agro.uva.es
}

This document is the accepted manuscript version of the following article: Eugenio, M., Olano, J. M., \& Fonti, P. (2014). Disentangling the effects of ontogeny and environmental factors on xylem anatomy in a semiarid chamaephyte. Journal of Arid Environments, 104, 1-8. https://doi .org/10.1016/j.jaridenv. 2014.01.014 


\begin{abstract}
The hydraulic system of plants reflects a balance between efficiency and safety which is continuously adjusted along plant's life to guarantee survival under changing conditions. One of such adjustments is the formation of new conductive cells, so vessel traits along ring series reflect part of plant's hydraulic plasticity. In this work we disentangled the effects of ontogeny and environmental factors on wood anatomy of a semiarid chamaephyte, Linum suffructicosum. We sampled individuals on contrasting slope aspects in the Ebro valley (Spain), and measured ring width and vessel traits to obtain annually-resolved data series. General Additive Models (GAMs) were used to identify the variability associated to cambial age, slope aspect, and climatic factors: a shift towards a more efficient xylem configuration was observed at the eighth year of life; narrower rings characterized by higher vessel density and smaller vessel sizes were found at south-facing slopes, and low precipitation at the onset of the growing season resulted in safer vessel features. The combination of quantitative analysis of vessels along ring series and GAMs allowed a global understanding of xylem's functional plasticity; moreover, the need for adequately assessing ontogenetic and topographic effects when predicting plant distribution under global change scenarios was reinforced.
\end{abstract}

Keywords: Chamaephytes; climatic change; dendrochronology; drought; gypsum soils; xylem quantitative anatomy. 


\section{Introduction}

Water plays a fundamental role in the life of a plant. Understanding how plants cope with water stress is becoming a major concern in the context of ongoing climatic change (IPCC 2007), and it is particularly urgent for arid and semiarid environments. Given the strong negative potential involved in water extraction from the soil and its transport up to the leaves, plants hydraulic systems often run close to physical limits (Tyree and Zimmerman 2002). Without some kind of safety mechanisms, air-seeding of gas may trigger cavitation and subsequent embolism, which would reduce transport efficiency, cause leaf desiccation and eventually plant death. On the other hand, over-developed safety mechanisms may result in reduced water transport and/or higher resource investment, and thus would reduce plant performance and competitive ability (Sperry et al. 2008; McDowell 2011).

Plants show a range of responses occurring at different time scales to withstand fluctuating levels of water availability (Maseda and Fernandez 2006), including stomatal closure (Tyree and Ewers 1991; Zweifel et al. 2009), shifts in the shoot-to-root growth ratio (Kleint et al. 2011), modifications of the leaf and sap area (Rigling et al. 2010), and changes in xylem anatomy (Tyree and Zimmermann 2002). Performing adjustments in the topology, density, and size of conductive cells is an effective and relatively fast mechanism to regulate the delicate balance between cavitation risks and efficiency in water transport (Mauseth and Stevenson 2004, von Arx 2012). Thus, treering series of cell anatomical features constitute a chronological archive of past plantwater relations (e.g., Fonti et al. 2010; Olano et al. 2012). Understanding the patterns of xylem adjustments to climate, and the relative importance of the different factors affecting xylem anatomy, is essential to anticipate the potential impacts of climatic 
change on plant performance. For example, the regional climatic signal may be modified by the effects of local site characteristics such as slope aspect; thus, in Northern Hemisphere semiarid environments, north-facing aspects show more favorable conditions for plant growth, since they receive less solar radiation than south-facing slopes (Bellot et al. 2004; Pueyo and Alados 2007). In addition, changes in plant growth requirements that occur along the lifecycle can further confound the importance of climate. Such age-size-related trends, despite usually being considered noise in dendroclimatic studies, strongly influence wood structure (Spicer and Gartner 2001; Domec and Gartner 2002), particularly in short- to medium-lived plants such as subshrubs (Biondi and Queadan 2008).

Despite largely neglected in dendrochronological literature, sub-shrubs constitute a dominant life form in arid and semiarid ecosystems. In fact, semiarid scrublands dominate vast areas of the landscape in the Mediterranean Basin, where water availability is low in general, and highly variable at contrasting spatial and temporal scales (Sher et al. 2004). The projected increase in the frequency and severity of droughts for this region (Schär et al. 2004) may strongly affect these ecosystems. Potentially drier and warmer conditions are expected to result in altered phenological timing (Llorens and Peñuelas 2005), reduced growth and primary production (Ogaya et al. 2003), shifted recruitment patterns (Olano et al. 2011), and enhanced mortality rates (McDowell et al. 2008; Allen et al. 2010). Anatomical traits have also been correlated with water stress in shrub species (Jacobsen et al. 2007; Martínez-Cabrera et al. 2009).

In this study, we assessed radial growth and vessel traits in the chamaephyte Linum suffructicosum L., which inhabits low scrublands on both gypsum and calcareous soils in South-western Europe (Ockendon and Walters 1968), thus being considered a 
gypsovag (sensu Meyer 1986). Specifically, our aims were to a) better understand the relative contribution of age, slope aspect and climate to radial growth and xylem anatomical characteristics, and b) describe the adjustments in vessel size classes performed by the species in relation to site and climate conditions. To simultaneously assess the effect of multiple factors on annual ring characteristics, Generalized Additive Models (GAM) were used.

\section{Materials and methods}

\subsection{Study site and species description}

The study was conducted in the central Ebro Valley, North-eastern Spain $\left(41^{\circ} 41^{\prime} \mathrm{N}, 0^{\circ}\right.$ 46’ W, $242 \mathrm{~m}$ a.s.1.). Climate is semiarid Mediterranean, characterised by an intense summer drought and a mean annual rainfall of $320 \mathrm{~mm}$. Mean annual temperature is $15.0^{\circ} \mathrm{C}$, with a mean minimum temperature in the coldest month of $2.4^{\circ} \mathrm{C}$ and a mean maximum temperature in the hottest month of $31.5^{\circ} \mathrm{C}$ (data from Zaragoza meteorological station, $41^{\circ} 39^{\prime} 23^{\prime}{ }^{\prime} \mathrm{N}, 0^{\circ} 52^{\prime} 45^{\prime}$ ' W, $208 \mathrm{~m}$ a.s.1.). Soils are developed on gypsum parent rocks, and consequently are rich in calcium sulphate. The landscape is characterized by low hills and flat-bottomed valleys, and is covered by a low open scrubland where L. suffruticosum is abundant.

Gypsum steppes occurring under semiarid climates are subjected to harsh environmental conditions, given their physically (Romão and Escudero 2005) and chemically (Guerrero-Campo et al. 1999b) restrictive soils, and the existence of an intense summer drought (Olano et al. 2011). L. suffruticosum is an evergreen and medium-lived chamaephyte showing distinct rings and semi-ring-porous wood (Fig. 1). 
It grows up to $40 \mathrm{~cm}$ tall and constitutes a major component of gypsum steppes in South-western Europe (Ockendon and Walters 1968). Vegetative and reproductive activity of the species takes place during spring and autumn; its longitudinal growth shows a main pulse from mid-February to the end of June, and a second pulse from September to November (Palacio and Montserrat-Martí 2005). Radial growth extends from April to June (Camarero et al. 2013).

\subsection{Sampling, sample preparation and anatomical survey}

Two samplings were performed in January 2010. A first sampling was performed at Villamayor (Zaragoza-Spain), where 20 dominant individuals per aspect were selected from the north-facing and south-facing slopes of a hill (N-site and S-site). Height and two canopy diameters were measured on each individual, and afterwards plants were extracted. Root collars were cut and immediately stored in a fixative solution of formalin-ethanol-acetic acid (5:90:5).

Since the obtained chronology spanned a relative short period of time for standard dendrochronological climate-growth analysis, a second sampling of 20 dominant individuals was subsequently performed on the south-facing slope of a hill at Alfajarín (Zaragoza-Spain, $3 \mathrm{~km}$ away from Villamayor) by following the same sampling procedure. The Alfajarín site was characterised by harsher environmental conditions (steeper slope, rockier soil), and therefore we expected to obtain older individuals from it, since environmental stress is known to extend life spans as a result of reduced growth (Schweingruber and Poschlod 2005). Such older individuals from Alfajarín allowed us to obtain temporal series long enough to reliably perform statistical correlations of residual growth-climate following classic techniques; the aim was exclusively to detect the most relevant climatic parameters determining ring width and vessel features in 
order to include them in the statistical analysis conducted with data from Villamayor (thus reducing the number of parameters included in the models, and at the same time ensuring the reliability of the selected climatic variables).

We acknowledge that, since an only field site was sampled and no replication of northand south- facing slopes was included in the statistical analyses, our results must be taken with caution. Nevertheless, and given that aspect is one the major ecological factors acting at local scales in semiarid environments (Guerrero-Campos et al. 1999a; Pueyo and Alados 2007), we are confident of the representativeness of our results.

Digital images of the cross-sections of root-collars were used to perform ring width measurements. Micro-sections 10 to $15 \mu \mathrm{m}$-thick were obtained by means of a sledge microtome $\left({ }^{\odot}\right.$ H. Gärtner / F.H. Schweingruber, Birmensdorf, Swirzerland), stained with Alcian Blue (1\% solution in $0.7 \mathrm{~N} \mathrm{HCl})$ and Safranin (1\% water soluble), and permanently embedded with Eukitt® glue (O. Kindler GmbH, Freiburg, Germany). Digital images were captured using a Nikon D-90 digital camera mounted on a Nikon Eclipse 50i optical microscope with a 40x magnification. Ring widths were measured along two radii per cross-section by using the image analysis software Image Pro Plus (version 6.0 for Windows XP x64. Media Cybernetics, Inc., Silverspring, Maryland, USA).

As a first step, visual cross-dating was performed and chronology quality was checked with COFECHA for individuals equal to or older than 10 years (Holmes 1983). Crossdating is an essential procedure in dendrochronology that ensures the correct assignation of an annual ring to a specific calendar year (Speer 2010); just by counting rings from bark to pith is not accepted, since it may lead to errors due to the existence of false or absent rings. 
Plants whose correlation values with master ring width chronology were over 0.45 were selected to conduct vessel anatomical measurements. At Villamayor, 11 plants per aspect were selected $(n=22)$. At Alfajarín, exclusively 6 plants aged between 17 and 21 years were selected (those providing with long enough series as to conduct reliable correlations with climatic parameters).

From the selected subset of plants, new images were obtained along one radius on the cross-section, and at a 200x magnification, for anatomical analysis. Images were analyzed from the outermost ring to the pith; a total sample of 100 vessels was considered at each ring. Vessels were automatically identified by using a size filter (minimal lumen area of $20 \mu \mathrm{m}^{2}$ ), and such identification was visually checked to correct misrecognitions. For each vessel, mean lumen diameter and lumen area were measured. The analysed ring area was also measured in order to calculate vessel density. These data provided with annually-resolved information on: (i) vessel density; (ii) percentage of vessel lumen area $=\left(S_{\mathrm{i}} / \text { total surface }\right)^{*} 100$, where $\mathrm{S}=$ vessel lumen area; and (iii) the hydraulically weighted mean diameter $=\sum \mathrm{d}_{\mathrm{i}}{ }^{5} / \sum \mathrm{d}_{\mathrm{i}}{ }^{4}$, where $\mathrm{d}=$ vessel mean diameter (Kolb and Sperry 1999).

Finally, the frequency of vessels per $2 \mu \mathrm{m}$-diameter classes, and the relative contribution of each class to total water flow (sum of the fourth power of the radius of each vessel in the class, according to Poiseuille) were calculated for each year and individual from Villamayor site. Additionally, frequency distributions of vessel diameter classes, contribution of each vessel class to potential conductivity and the vessel size category at which $50 \%$ of total water flow is achieved were calculated separately for individuals at the N- and S-facing sites for years 2004 and 2005. These specific climatic years were selected because they represent extreme wet and dry spring 
conditions, respectively, and occurred when most sampled individuals were already at a mature stage (thus avoiding age-related confounding effects).

\section{Statistical analyses}

General linear models were performed to test for differences in plant size (height and mean canopy diameter) between the $\mathrm{N}$ - and S-facing slopes of the Villamayor site; and age of the individuals was considered as a covariate. Analyses were conducted with PASW Statistic v. 18 (2009. Chicago: SPSS Inc).

Relevant climatic parameters affecting ring width and xylem anatomy were detected with the longer chronology (1990-2009) developed at Alfajarín. Index chronologies were constructed for every response variable (ring width, vessel density, vessel conductive area and mean vessel hydraulic diameter) by averaging the linearlystandardized individual time-series. Multiple regressions were computed between such index chronologies and normalized climatic variables, including monthly average temperature $(\mathrm{T})$, and monthly accumulated precipitation $(\mathrm{P})$ for previous winter (December to February) and current spring (March to May) (climatic data for the Zaragoza meteorological station were obtained from the Spanish Meteorological Agency, www.aemet.es). These periods were selected according to the existing knowledge on Linum xylogenesis (Camarero et al. 2013). Variables were included according to the Wald's forward stepwise procedure; the cut-off value for inclusion was 0.05 , and 0.1 to exclude a previously included variable. Statistical analyses were performed with PASW Statistic v. 18 (2009. SPSS Inc, Chicago, Illinois, USA). 
Climatic variables that were shown to exert significant influence on radial growth and vessel-related parameters at Alfajarín site were selected to be included in subsequent analyses on the shorter time-series from Villamayor locality. This procedure was performed to reduce the number of climatic parameters included in the models, and at the same time ensuring their reliability. A preliminary exploration of our data set indicated that age-related trends were not linear along the lifespan of L. suffruticosum individuals. Thus, and in order to distinguish the relative effects of age, aspect, and climate in ring width and anatomical variables (vessel density, vessel conductive area and mean vessel hydraulic diameter), a generalized additive model (GAM) (Hastie and Tibshirani 1986) was selected. GAMs are a flexible extension of the Generalized Linear Models (McCullagh and Nelder 1989; Zuur et al. 2009) allowing the inclusion of linear and non-linear complex response shapes in one model. The ability to model non-linear responses may be particularly useful to model the complex pattern of ontogenetic trends occurring in short to medium- lived perennials. Thus, the fixed part of every model included cambial age (equivalent to plant age), aspect and those climatic parameters revealed to be significant in multiple regression computations from Alfajarín site. All two-term interactions were also included. Based on preliminary exploration, cambial age was modeled with a smoother (Zuur et al. 2009), and linear relations were assumed for the rest of parameters. It is important to remark that this approach was selected because it has the potential to distinguish age-related effects from aspect or climatic effects even for individuals belonging to the same cohort.

To construct every GAM, the process suggested by Zuur et al. (2009) was followed. Firstly, the optimal random structure was selected for each response parameter among several variance structures for the fully fixed structure: 1) no variance structure, 2) a 
plant-based variance structure, 3) a power covariate variance structure based on age, 4) a power covariate structure based on age nested on plant, and 5) a variance structure combining 2 and 3. The optimal random structure was selected based on Akaike Information Criteria (AIC), estimated by means of the restricted maximum likelihood method (REML). Homocedasticity of residuals was also visually checked. In the second step, the optimal fixed structure was selected based on comparison of all potential nested models. Again, the best model was selected based on AIC, in this case estimated by means of maximum likelihood method (ML). When several models showed similar AIC values $(\triangle \mathrm{AIC}<2$, Burnham and Anderson 2002), the model with the simplest fixed component was chosen for the sake of parsimony. Once selected, the best model was refitted by means of REML to obtain estimates of factor effects and their significance. Statistical analyses were performed with nmle (Pinheiro et al. 2011) and mgcv (Wood 2011) packages under R environment, version 2.13.1 (R Development Core Team 2011).

\section{Results}

\subsection{Plant age}

Age (mean $\pm \mathrm{SE}$ ) of L. suffruticosum individuals ranged between 6 and $15 \mathrm{yr}$ at the Villamayor N-site, with a mean value of $11.1 \pm 0.64 \mathrm{yr}$. Overall, $35 \%$ of individuals had established in 1997 (13 yr-old), and 25\% in 2002 (8 yr-old). At the Villamayor S-site, age ranged between 6 and $20 \mathrm{yr}$, with a mean value of $12.8 \pm 0.69 \mathrm{yr}$. Again, 35\% of individuals established in 1997 (13 yr-old), and another 35\% in 1996 (14 yr-old). At Alfajarín site, age ranged between 5 and $21 \mathrm{yr}$, with a mean value of $15.2 \pm 0.93 \mathrm{yr}$. The 
most abundant cohort in our sampling was established in 1996 (30\%). Individuals selected for climatic analysis were the oldest $(19.5 \pm 0.67 \mathrm{yr})$.

\subsection{Plant size}

In Villamayor, mean canopy diameter (mean \pm SE) of L. suffruticosum individuals was significantly higher at the $\mathrm{N}$-site, $18.8 \pm 1.3 \mathrm{~cm}$, than at the $S$-site, $15.3 \pm 1.1 \mathrm{~cm}(\mathrm{n}=40$; $F=9.18 ; P=0.004)$. Mean plant height did not significantly differ between aspects $(\mathrm{N}-$ site $29.6 \pm 7.7 \mathrm{~cm}, \mathrm{~S}$-site $27.7 \pm 8.8 \mathrm{~cm} ; \mathrm{n}=40 ; F=3.63 ; P=0.065)$. The covariate plant age showed a positive and significant effect on canopy diameter $(F=10.81 ; P=$ $0.002)$ and plant height $(F=15.64 ; P<0.001)$.

\subsection{Selection of climatic parameters}

Relevant climatic variables influencing ring features in L. suffruticosum were identified from Alfajarín chronology based on six plants for the 1990-2009 period by using multiple regressions. Ring width model $\left(R_{a d j}^{2}=0.45 ; F=8.69 ; P=0.003\right)$ indicated a positive effect of January precipitation $(\beta$ coef. $=0.40 ; t=2.30 ; P=0.034)$ and March precipitation $(\beta$ coef. $=0.61 ; t=3.56 ; P=0.002)$. Vessel density model $\left(R_{\text {adj }}^{2}=0.39 ; F\right.$ $=7.01 ; P=0.006)$ indicated a negative effect of January temperature $(\beta$ coef. $=-0.42 ; t$ $=-2.32 ; P=0.033)$ and March precipitation $(\beta$ coef. $=-0.452 ; t=-2.48 ; P=0.024)$. Model for mean vessel hydraulic diameter $\left(R_{a d j}^{2}=0.17 ; F=4.98 ; P=0.039\right)$ indicated a positive effect of March precipitation $(\beta$ coef. $=0.47 ; t=2.23 ; P=0.039)$. Lastly, no significant model was obtained for vessel conductive area.

\subsection{Determining the effects of age, aspect, and climate}

Climatic variables showing significant effects on Alfajarín chronologies and their interactions were included in the fixed part of the corresponding GAM models for 
Villamayor data (March and January P for RW; March P and January $\mathrm{T}$ for vessel density; March P for mean hydraulic diameter; no climatic factor was included for vessel conductive area). The selected optimal random structure was the same for all response variables, and included both a plant-based variance structure and a power covariate variance structure based on age. All final models explained high percentages of total variances: Ring width (plants $=40 ; \mathrm{n}=457 ; R^{2}{ }_{a d j}=0.86 ; P<0.001$ ), mean vessel hydraulic diameter (plants $=22 ; \mathrm{n}=282 ; R_{a d j}^{2}=0.97 ; P<0.001$ ), vessel density (plants $=22 ; \mathrm{n}=272 ; R^{2}{ }_{a d j}=0.96 ; P<0.001$ ), and percentage of vessel lumen area (plants $\left.=22 ; \mathrm{n}=273 ; R_{a d j}^{2}=0.82 ; P<0.001\right)$.

The GAM model for ring width indicated that this variable was strongly dependent on plant age: it sharply increased during the first 8 years of life, before stabilizing (estimated degrees of freedom $(e d f)=5.20 ; F=93.09 ; P<0.001)$ (Fig. 2a). Ring width also varied between aspects (Fig. $2 \mathrm{~b}$ and $3 \mathrm{a}$ ), with individuals at the $\mathrm{N}$-site showing higher growth $(\beta$ South $=-104.76 ; t=-10.68 ; P<0.0001)$. Among pre-selected climatic signals, March rainfall showed a positive effect on ring width $(\beta=8.27 ; t=2.38 ; P=$ $0.018)$, as did the interaction between January precipitation and aspect $(\beta$ South $=19.07$; $t=3.57 ; P<0.001)$. Average values of ring width were $123.2 \pm 12.7 \mu \mathrm{m}$ at the $\mathrm{N}$-site and $93.3 \pm 6.7 \mu \mathrm{m}$ at the S-site for $1 \mathrm{yr}$-old individuals, and $385.6 \pm 27.0 \mu \mathrm{m}$ and 292.0 $\pm 19.4 \mu \mathrm{m}$ for 8 yr-old individuals (Fig. 2b).

A similar pattern was found for mean hydraulic diameter, which tended to increase during the first 8 years, stabilizing afterwards (edf $=5.54 ; F=110.4 ; P<0.001)$ (Fig. 2c). Aspect also had a significant effect (Fig. 2d and 3b), with higher mean hydraulic diameters recorded in plants on $\mathrm{N}$-facing slopes $(\beta$ South $=-1.27 ; t=-4.52 ; P<0.0001)$. Mean values of hydraulic diameter were $9.4 \pm 1.5 \mu \mathrm{m}$ at the $\mathrm{N}$-site and $6.2 \pm 0.7 \mu \mathrm{m}$ at 
the S-site in 1 yr-old individuals, and $19.8 \pm 1.3 \mu \mathrm{m}$ at the $\mathrm{N}$-site and $18.0 \pm 0.8 \mu \mathrm{m}$ at the S-site in 8 yr-old ones (Fig. 2d). Finally, March precipitation exerted a positive effect on mean hydraulic diameter $(\beta=0.40 ; t=2.608 ; P=0.0096)$.

Vessel density decreased linearly with cambial age ( $e d f=1 ; F=16.02 ; P<0.001)$ (Fig. 2e) and differed between aspects (Fig $2 \mathrm{f}$ and $3 \mathrm{c}$ ), with individuals at the S-site showing higher vessel density $(\beta$ South $=0.01 ; t=5.14 ; P<0.001)$. High initial values of density were recorded: $516.9 \pm 137.3 \mathrm{vessel} / \mathrm{mm}^{2}$ at the $\mathrm{N}$-site and $716.0 \pm 176.0 \mathrm{vessel} / \mathrm{mm}^{2}$ at the S-site, respectively (Fig. 2f). Climatic variables were not included in the final model.

Percentage of vessel lumen area showed a clear age-related trend, characterized by increasing values from the first year $(2.66 \pm 0.71 \%)$ to the eighth year $(8.45 \pm 0.70 \%)$, before stabilization after this point ( $e d f=3.81 ; F=71.67 ; P<0.001)$ (Fig. $2 \mathrm{~g}$ and $2 \mathrm{~h}$ ). Aspect showed no significant effect on vessel lumen area (Fig $2 \mathrm{~h}$ and $3 \mathrm{~d}$ ).

\subsection{Vessel size classes and their relative contribution to total vessel conductivity}

The frequency distribution of vessel sizes, as well as such vessel size classes' relative contribution to total hydraulic conductivity for the wet year 2004 and the dry year 2005, illustrate how aspect may influence plants' response to climate (Fig.4). Under drier conditions, a shift towards smaller vessel sizes is observed at both slopes (Fig. 4a), which presumably resulted in water flowing through a narrower range of safer but less efficient vessels (Fig. 4b). Values of vessel size class at which $50 \%$ of total water flow is achieved were consistently higher at the $\mathrm{N}$-site than at the S-site, indicating that aspect played a more important role in determining hydraulic characteristics than 
strongly differing climatic years. It must be underlined that in 2004-2005 most individuals were older than 7 years, thus at the mature stage characterized by low age effects on vessel size.

\section{Discussion}

Xylem anatomy along ring series provides a permanent record of annual plant adjustments to varying levels of water availability. Wood anatomy of the semiarid chamaephyte L. suffruticosum revealed a strong influence of ontogeny and environmental factors (slope aspect and climate) on the hydraulic system, as firmly supported by previous evidences linking the cellular structure of xylem with wholeplant hydraulic function (Carlquist and Hoekman 1985; Tyree and Ewers 1991; Carlquist 2001; Tyree and Zimmermann 2002; Wheeler et al. 2007; Sperry et al. 2008; Martínez-Cabrera et al. 2009; Poorter et al. 2010).

Changes in vessel characteristics over plant's life reflected the link between plant's size and its ability to access soil water. In the first year of life, wood was characterized by a high density of very narrow vessels. This could be interpreted as the need for safe water transport under conditions of limited access to water, as expected in seedlings with incipient root systems. In the following seven years, there was a sharp increase in vessel size, radial growth, and the percentage of vessel lumen area, all of which would suggest an increasingly efficient water transport system, presumably related to an improved access to water provided by developing roots. Overall, such trends may reflect the existence of a more marked water-stress in young plants, consistent with the observed high mortality rates in plants living on gypsum soils during the first summer drought 
after emergence (Escudero et al. 2000; DelaCruz et al. 2008; Quintana-Ascencio et al. 2009), which leads to cohort-structured populations (Olano et al. 2011). In our Linum, radial growth, vessel size, and the percentage of vessel lumen area leveled-off after the seventh year of life, suggesting full plant development at that age.

Previous works on conifer tree species suggest that ontogenetic changes in wood anatomy have evolved primarily to provide with hydraulic safety in long distance water transport (Spicer and Gartner 2001; Domec and Gartner 2002; Meinzer et al. 2011). Ontogenetic trends are known to reflect an adaptative compromise between developmental constraints and the environment (Denne and Dodd 1981; Metcalfe and Stock, 1987; Olano et al. 2013), and that is why they should be carefully modeled and interpreted, rather than routinely removed by means of standardization procedures. This may be particularly important in short- to medium-lived plant species, in which the juvenile phase constitutes a proportionally longer phase of the lifecycle.

Vessel traits in L. suffruticosum also varied in relation to site conditions, as observed when comparing between $\mathrm{N}$ - and S-facing slope aspects of the same site. Under semiarid conditions, insolation and water-stress are known to be higher at south-facing aspects (Bellot et al. 2004; Soliveres et al. 2010), a fact which strongly conditions vegetation distribution patterns (Guerrero-Campo et al. 1999a; Pueyo and Alados 2007). Although we must be cautious with this result because only two slopes were considered, plant growth at the S-site was reduced with respect to the $\mathrm{N}$-site, as revealed by the lower values of canopy size and mean ring width. Accordingly, wood anatomy of the Ssite individuals was characterized by safety-oriented traits, such as lower hydraulic diameters and higher vessel densities (Mauseth and Stevenson 2004; Stevenson and Mauseth 2004). These results are consistent with decreasing vessel diameter associated 
with aridity, which is observed at intra-specific (Villar-Salvador et al. 1997) and interspecific (Baas 1986; Woodcock et al. 2000) levels, while vessel densities increase from mesic to xeric environments (Fahn et al. 1986; Carlquist 1989).

The 'safer' xylem anatomic features observed in southern-aspect plants might suggest that cavitation risks occur at lower soil water potentials in these individuals, which, however, should not be interpreted as northern-aspect plants being more prone to cavitation. Firstly, northern-aspect plants face substantially better local conditions than southern-facing plants, despite growing under the same regional climatic conditions. Secondly, there are many other vessels traits (such as pit area, vessel length, wall thickness, e.g.; Lens et al. 2011) and plant architectural traits (such as leaf behavior and rooting) that can regulate stress resistance. Nevertheless, it is interesting to observe that xylem anatomy showed safer traits at the southern aspect site during a wet year (2004) than at the northern aspect site during a dry year (2005), which evidences the strong significance of aspect, and reinforces the need for adequately assessing topographic effects when predicting plant distribution under global change scenarios (Scherrer and Körner 2010). If a minimum threshold size determining effective water conduction by vessels would exist, individuals at southern aspects would be operating closer to their physiological limits, and thus may be more vulnerable to enhanced drought, which in turn could explain the higher mortality rates reported at south-facing slopes during drought episodes in Mediterranean woody plants (Peñuelas et al. 2000).

Finally, radial growth and vessel traits along ring series also responded to inter-annual climatic variability, and particularly to water availability at the onset of the growing season. Growth responses to March rainfall had already been reported in other gypsum shrubs growing under similar conditions (Soliveres et al. 2010), and are expectable 
since water is widely recognized as the main limiting factor for growth in semiarid environments. March rainfall also promoted the formation of larger vessels, probably due to higher turgor pressure during the cell expansion phase (Sass and Eckstein 1995; Schume et al. 2004). It is worth noting that a positive effect of January rainfall on ring width also existed, which may be related to replenishment of water soil budget before the onset of annual-ring formation, as already found in this area (DeSoto et al. 2012).

In our study, the use of GAMs allowed the modeling of complex age-related trends and plant responses to environmental factors, thus paving the way to use annually-resolved data series from a wide range of species. Overall, our results highlight the importance of distinguishing between the contributions of the different factors that determine xylem anatomy and secondary growth, in order to better understand potential plant responses to climate change. Ontogeny was the major factor determining secondary growth and hydraulically relevant vessel traits along the lifecycle. Aspect modulated the impact of climate under the particularly harsh conditions of semiarid gypsum steppes, and played a more important role in determining hydraulic characteristics than strongly differing climatic years. Lastly, climate affected radial growth and xylem traits, mainly through water availability at the beginning of the growing season. Xylem anatomy was mostly controlled by ontogeny and aspect; however, inter-annual variations were related to climatic conditions, what suggests that the importance of water stress is likely to increase in the future, related to global warming. 


\section{Acknowledgments}

Authors thank L Schneider for training us on preparing histological sections and $\mathrm{M}$ Folch and J Recio for assisting us with the quantitative vessel analysis. G von Arx, JC Linares, and L Cayuela very kindly responded to our questions on statistical analyses. David Brown edited the English. This work has been supported by Spanish MICINN and MINECO projects CGL2009-13190-C03-03 and CGL2012-34209 and Junta de Castilla y León project VA006A10-2. This study profited from discussions within the framework of the COST Action STReESS (FP 1106). 


\section{References}

Allen, C.D., Macalady, A.K., Chenchouni, H., Bachelet, D., McDowell, N., Vennetier, M., Kitzberger, T., Rigling, A., Breshears, D.D., Hogg, E.H., Gonzalez, P., Fensham, R., Zhang, Z., Castro, J., Demidova, N., Lim, J.H., Allard, G., Running, S.W., Semerci, A., Cobb, N., 2010. A global overview of drought and heat-induced tree mortality reveals emerging climate change risks for forests. Forest Ecology and Management 259, 660-684.

Baas, P., 1986. Ecological patterns in xylem anatomy. In: Givnish, T.J. (Ed.), On the economy of Plant form and function. Cambridge University Press, Cambridge, pp. 327-349.

Bellot, J., Maestre, F.T., Hernández, N., 2004. Spatio-temporal dynamics of chlorophyll fluorescence in a semi-arid shrubland. Journal of Arid Environments 58, 295-308.

Biondi, F., Queadan, F., 2008. A theory-driven approach to tree-ring standardization: defining the biological trend from expected basal area increment. Tree-Ring Research 64, 81-96.

Burnham, K.P., Anderson, D.R., 2002. Model selection and multimodel inference: a practical information theoretic approach. Springer-Verlag, Heidelberg.

Camarero, J.J., Palacio, S., Montserrat-Martí, G., 2013. Contrasting seasonal overlaps between primary and secondary growth are linked to wood anatomy in Mediterranean sub-shrubs. Plant Biology, 15:798-807.

Carlquist, S., 1989. Adaptive wood anatomy of chaparral shrubs. In: Keely, J.E. (Ed.), The California chaparral: paradigms re-examined. Los Angeles Country Museum of Natural History Contributions, Los Angeles, pp. 25-35. 
Carlquist, S., 2001. Comparative wood anatomy: Systematic, ecological, and evolutionary aspects of dycotiledon wood. Springer-Verlag, Berlin.

Carlquist, S., Hoekman, D.A., 1985. Ecological wood anatomy of the woody southern California flora. IAWA Bulletin 6, 319-347.

De la Cruz, M., Romão, R., Escudero, A., Maestre, F.T., 2008. Where do seedlings go? A spatio-temporal analysis of seedling mortality in a semi-arid gypsophyte. Ecography 31, 720730.

Denne, M.P., Dodd, R.S., 1981. The environmental control of xylem differentiation. In: Barnett, J.R. (Ed.) Xylem cell development. Castle House, Kent, pp. 236-255.

DeSoto, L., Camarero, J.J., Olano, J.M., Rozas, V., 2012. Geographically structured and temporally unstable growth responses of Juniperus thurifera to recent climate variability in the Iberian Peninsula. European Journal of Forest Research. doi: 10.1007/s10342-011-0564-7.

Domec, J.C., Gartner, B.L., 2002. Age- and position-related changes in hydraulic versus mechanical dysfunction of xylem: inferring the design criteria for Douglas-fir wood structure. Tree Physiology 22, 91-104.

Escudero, A., Iriondo, J.M., Olano, J.M., Rubio, A., Somolinos, R.C., 2000. Factors affecting establishment of a gypsophyte: the case of Lepidium subulatum. American Journal of Botany $87,861-871$. 
Fahn, A., Werker, E., Baas, P., 1986. Wood anatomy and identification of trees and shrubs from Israel and adjacent regions. The Israel Academy of Sciences and Humanities, Jerusalem.

Fonti, P., von Arx, G., García-González, I., Eilmann, B., Sass-Klaassen, U., Gärtner, H., Eckstein, D., 2010. Studying global change through investigation of the plastic responses of xylem anatomy in tree rings. New Phytologist 185, 42-53.

Guerrero-Campo, J., Alberto, F., Hodgson, J., García-Ruiz, J.M., Montserrat-Martí, G., 1999a. Plant community patterns in a gypsum area of NE Spain. I. Interactions with topographic factors and soil erosion. Journal of Arid Environments 41, 401-410.

Guerrero-Campo, J., Alberto, F., Hodgs, J., García-Ruiz, J.M., Montserrat-Martí, G., 1999b. Plant community patterns in a gypsum area of NE Spain. II. Effects of ion washing on topographic distribution of vegetation. Journal of Arid Environments 41, 411-419.

Hastie, T., Tibshirani, R., 1986. Generalized Additive Models. Statistical Science 1, 297-318.

Holmes, R.L., 1983. Computer-assisted quality control in tree-ring dating and measurement. Tree-Ring Bulletin 39, 77-82..

IPCC, 2007. Climate Change 2007: the physical science basis: contribution of Working Group I to the Fourth Assessment Report of the Intergovernmental Panel on Climate Change. Cambridge University Press, Cambridge.

Jacobsen, A.L., Agenbag, L., Esler, K.J., Pratt, R.B., Ewers, F.W., Davis, S.D., 2007. Xylem density, biomechanics and anatomical traits correlate with water stress in 17 evergreen shrub 
species of the Mediterranean-type climate region of South Africa. Journal of Ecology 95, 171183.

Klein, T., Cohen, S., Yakir, D., 2011. Hydraulic adjustments underlying drought resistance of Pinus halepensis. Tree Physiology 31,637-648.

Kolb, K.J., Sperry, J.S., 1999. Differences in drought adaptation between subspecies of sagebrush (Artemisia tridentata). Ecology 80, 2373-2384.

Lens, F., Sperry, J.S., Christman, M.A., Choat, B., Rabaey, D., Jansen, S., 2011. Testing hypotheses that link wood anatomy to cavitation resistance and hydraulic conductivity in the genus Acer. New Phytologist 190, 709-723.

Llorens, L., Peñuelas, J., 2005. Experimental evidence of future drier and warmer conditions affecting flowering of two co-occurring Mediterranean shrubs. International Journal of Plant Science $166,235-245$.

Maseda, P.H., Fernandez, R.J., 2006. Stay wet or else: three ways in which plants can adjust hydraulically to their environment. Journal of Experimental Botany 57, 3963-3977.

Mauseth, J.D., Stevenson, J.F., 2004. Theoretical considerations of vessel diameter and conductive safety in populations of vessels. International Journal of Plant Sciences 165, 359368.

Martínez-Cabrera, H.I., Jones, C.S., Espino, S., Schenk, H.J., 2009. Wood anatomy and wood density in shrubs: responses to varying aridity along transcontinental transects. American Journal of Botany 96, 1388-1398. 
McCullagh, P., Nelder, J.A., 1989. Generalized Linear Models. Chapman and Hall/CRC, Boca Raton, Florida.

McDowell, N., Pockman, W.T., Allen, C.D., Breshears, D.D., Cobb, N., Kolb, T., Plaut, J., Sperry, J., West, A., Williams, D.G., Yepez, E.A., 2008. Mechanisms of plant survival and mortality during drought: why do some plants survive while others succumb to drought? New Phytologist 178, 719-739.

McDowell, N.G., 2011. Mechanisms linking drought, hydraulics, carbon metabolism, and vegetation mortality. Plant Physiologist 155, 1051-1059.

Meinzer, F.C., Lachenbruchm, B., Dawson, T.E. (Eds.), 2011. Size and age-related changes in tree structure and function. Springer, Dordrecht.

Metcalfe, J., Stock, M.K., 1987. Physiological changes during ontogeny. In: Feder, M.E., Bennett, A.F., Burggren, W.W., Huey, R.B. (Eds.) New directions in ecological physiology. Cambridge University Press, Cambridge, pp. 328-341.

Meyer, S.E. 1986. The ecology of gypsophile endemism in the Eastern Mojave desert. Ecology, 67: 1303-1313.

Ockendon, D.J., Walters, S.M., 1968. Linum. In: Tutin, T.G., Heywood, V.H., Burges, N.A., Moore, D.M., Valentine, D.H., Walters, S.M., Webb, D.A. (Eds.) Flora Europaea, Vol. 2, Rosaceae to Umbelliferae. Cambridge University Press, Cambridge, pp. 206-211. 
Ogaya, R., Peñuelas, J., Martinez-Vilalta, J., Mangiron, M., 2003. Effect of drought on diameter increment of Quercus ilex, Phillyrea latifolia, and Arbutus unedo in a holm oak forest of NE Spain. Forest Ecology and Management 180, 175-184.

Olano, J.M., Eugenio, M., Escudero, A., 2011. Site effect is stronger than species identity in driving demographic responses of Helianthemum (Cistaceae) shrubs in gypsum environments. American Journal of Botany 98, 1-8.

Olano, J.M., Eugenio, M., García-Cervigón, A.I., Folch, M., Rozas, V., 2012. Quantitative tracheid anatomy reveals a complex environmental control of wood structure in continental Mediterranean climate. International Journal of Plant Science 173, 137-149.

Olano, J.M., Almería, I., Eugenio, M., von Arx, G., 2013. Under pressure: how a Mediterranean high-mountain forb coordinates growth and hydraulic xylem anatomy in response to temperature and water constraints. Functional Ecology. DOI: 10.1111/1365-2435.12144.

Palacio, S., Montserrat-Martí, G., 2005. Bud morphology and shoot growth dynamics in two species of Mediterranean sub-shrubs coexisting in gypsum outcrops. Annals of Botany 95, 949958.

Peñuelas, J., Filella, I., Lloret, F., Piñol, J., Siscart, D., 2000. Effects of a severe drought on water and nitrogen use by Quercus ilex and Phillyrea latifolia. Biologia Plantarum 43, 47-53.

Pinheiro, J., Bates, D., DebRoy, S., Sarkar, D., the R Development Core Team, 2011. Nlme: Linear and Nonlinear Mixed Effects Models. R package version 3.1-102. 
Poorter, L., McDonald, I., Alarcón, A., Fichtler, E., Licona, J., Peña-Claros, M., Sterck, F., Villegas, Z., Sass-Klaassen, U., 2010. The importance of wood traits and hydraulic conductance for the performance and life history strategies of 42 rainforest tree species. New Phytologist $185,481-492$.

Pueyo, Y., Alados, C.L., 2007. Effects of fragmentation, abiotic factors, and land use on vegetation recovery in a semi-arid Mediterranean area. Basic and Applied Ecology 8, 158-170.

Quintana-Ascencio, P.F., Caballero, I., Olano, J.M., Escudero, A., Albert, M.J., 2009. Does habitat structure matter? Spatially explicit population modelling of an Iberian gypsum endemic. Population Ecology 51, 317-328.

R Development Core Team, 2011. R: A language and environment for statistical computing. $R$ Foundation for Statistical Computing, Vienna. http://www.R-project.org.

Rigling, A., Eilmann, B., Koechli, R., Dobbertin, M., 2010. Mistletoe-induced crown degradation in Scots pine in a xeric environment. Tree Physiology 30, 845-852.

Romão, R.L., Escudero, A., 2005. Gypsum physical soil crusts and the existence of gypsophytes in semi-arid central Spain. Plant Ecology 181, 127-137.

Sass, U., Eckstein, D., 1995. The variability of vessel size in beech (Fagus sylvatica L.) and its ecophysiological interpretation. Trees 9, 247-252.

Schär, C., Vidale, P.L., Luethi, D., Frei, C., Häberli, C., Liniger, M.A., Appenzeller, C., 2004. The role of increasing temperature variability in European summer heatwaves. Nature 427, 332336. 
Scherrer, D., Körner, C., 2010. Infra-red thermometry of alpine landscapes challenges climatic warming projections. Global Change Biology 16, 2602-2613.

Schweingruber, F.H., Poschlod, P., 2005. Growth Rings in Herbs and Shrubs: life span, age determination and stem anatomy. Forest Snow Landscape Research 79, 195-415.

Sher, A.A., Goldberg, D.E., Novoplansky, A., 2004. The effect of mean and variance in resource supply on survival of annuals from Mediterranean and desert environments. Oecologia $144,353-362$.

Schume, H., Grabner, M., Eckmullner, O., 2004. The influence of an altered groundwater regime on vessel properties of hybrid poplar. Trees 18, 184-194.

Soliveres, S., DeSoto, L., Maestre, F.T., Olano, J.M., 2010. Spatio-temporal heterogeneity in abiotic factors modulate multiple ontogenetic shifts between competition and facilitation. Perspectives in Plant Ecology, Evolution and Systematics 12, 227-234.

Speer, J.H., 2010. Fundamentals of tree ring research. The Universisty of Arizona Press, Tucson.

Sperry, J.S., Meinzer, F.C., McCulloh, M.A., 2008. Safety and efficiency conflicts in hydraulic architecture: scaling from tissues to trees. Plant, Cell and Environment 31, 632-645.

Spicer, R., Gartner, B.L., 2001. The effects of cambial age and position within the stem on specific conductivity in Douglas-fir (Pseudotsuga menziesii) sapwood. Trees 15, 222-229. 
Stevenson, J.F., Mauseth, J.D., 2004. Effects of environment on vessel characters in cactus wood. International Journal of Plant Science 165, 347-357.

Tyree, M.T., Ewers, F.W., 1991. The hydraulic architecture of trees and other woody-plants. New Phytologist 119, 345-360.

Tyree, M.T., Zimmermann, M.H., 2002. Xylem structure and the Ascent of Sap, 2nd edn. Springer-Verlag, New York.

Villar-Salvador, P., Castro-Díez, P., Pérez-Rontomé, C., Montserrat-Martí, G., 1997. Stem xylem features in three Quercus (Fagaceae) species along a climatic gradient in NE Spain. Trees 12, 90-96.

von Arx, G., Archer, S., Hughes, M., 2012. Long term functional plasticity in plant hydraulic architecture in response to supplemental moisture. Annals of Botany 109(6), 1091-1100.

Wheeler, E.A., Baas, P., Rodgers, S., 2007. Variations in dicot wood anatomy: a global analysis based on the Insidewood data-base. IAWA Bulletin28, 229-258.

Wood, S.N., 2011. Fast stable restricted maximum likelihood and marginal likelihood estimation of semiparametric generalized linearmodels. Journal of the Royal Statistical Society $73,3-36$.

Woodcock, D.W., Dos Santos, G., Reynel, C., 2000. Wood characteristics of Amazon forest types. IAWA Bulletin 21, 277-292. 
Zuur, A.F., Leon, E.N., Walker, N., Saveliev, A.A., Smith, G.M., 2009. Mixed effects models and extensions in ecology with R. Springer, New York.

Zweifel, R., Rigling, A., Dobbertin, M., 2009. Species- specific stomatal response of trees to drought - a link to vegetation dynamics?. Journal of Vegetation Science 20, 442-454. 
Figures

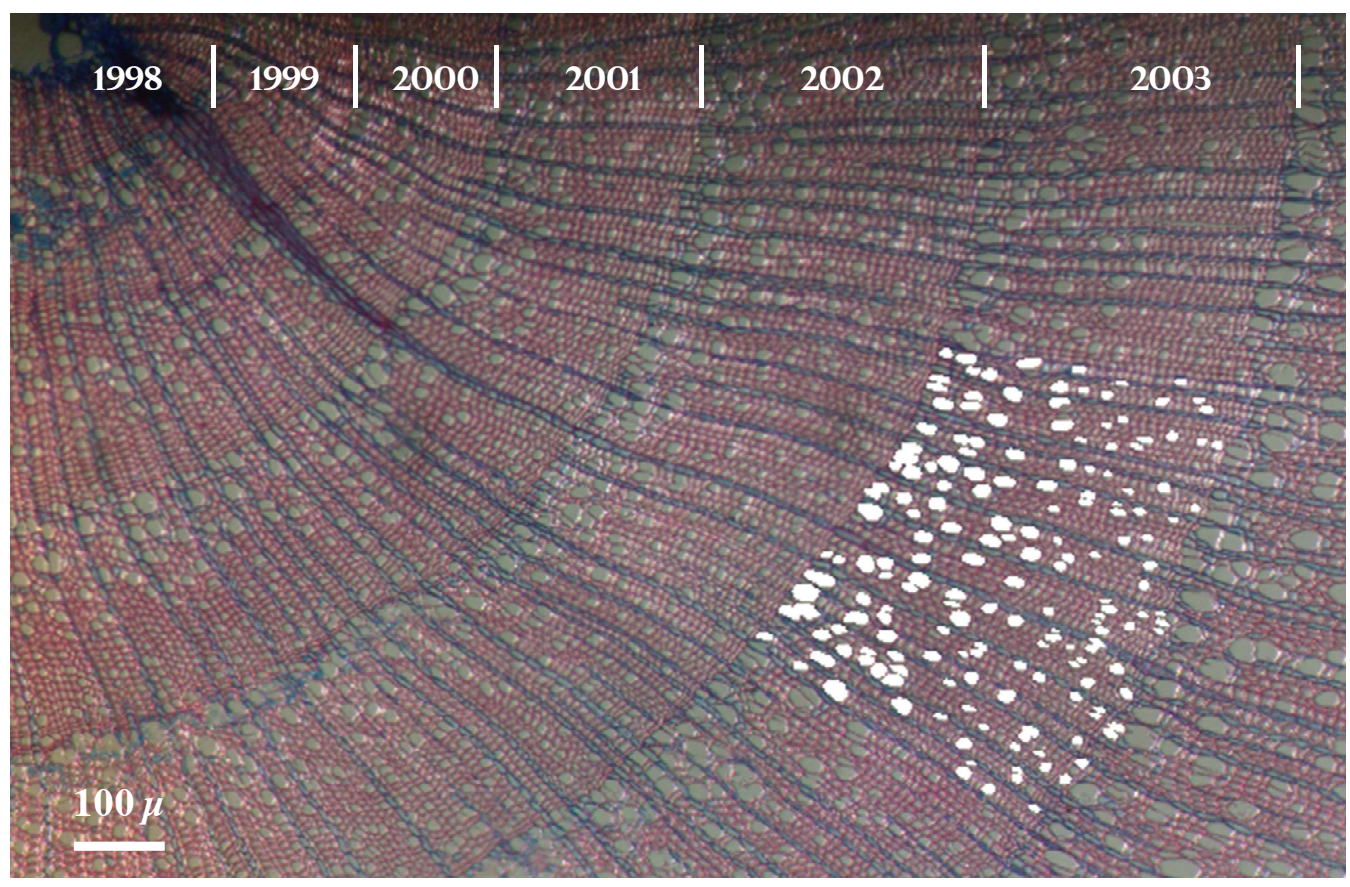

Fig. 1. Permanent histological cross-section of L. suffruticosum. Staining conducted with Alcian Blue $(1 \%$ solution in $0.7 \mathrm{~N} \mathrm{HCl})$ and Safranin $(1 \%$ water soluble); digital images captured with a Nikon D-90 digital camera mounted on a Nikon Eclipse 50i optical microscope. Scale (down left), dating (below the top), and identified vessels (on year 2003) are indicated. 

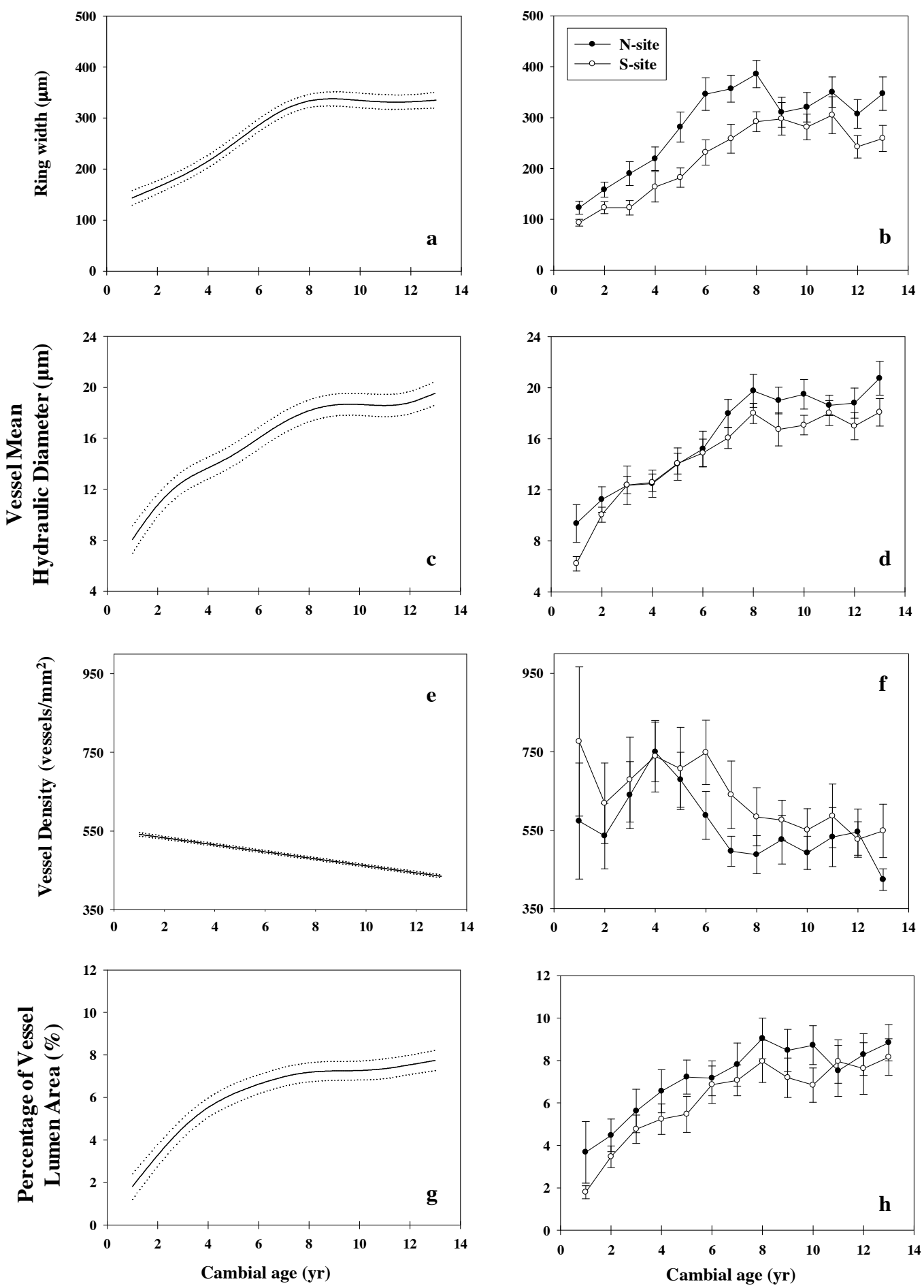

Fig. 2 Trends of response variables along cambial age and slope aspect for Linum individuals at Villamayor: (a) Estimated age effect for ring width based on GAM, edf= 5.20, (b) Ring width, (c) 
Estimated age effect for mean hydraulic diameter based on GAM, edf $=5.54$, (d) Mean hydraulic diameter, (e) Estimated age effect for vessel density based on GAM, edf= 1, (f) Vessel density, (g) Estimated age effect for percentage of vessel lumen area based on GAM, $e d f=3.81$, (h) Percentage of vessel lumen area. Dotted-lines (a, c, e, g) and bars (b, d, f, h) indicate standard errors. Note that values for age effect (a, c, e, g) differ from mean value for a parameter at a given age; to obtain mean value, climatic and aspect effects should be added or subtracted. 

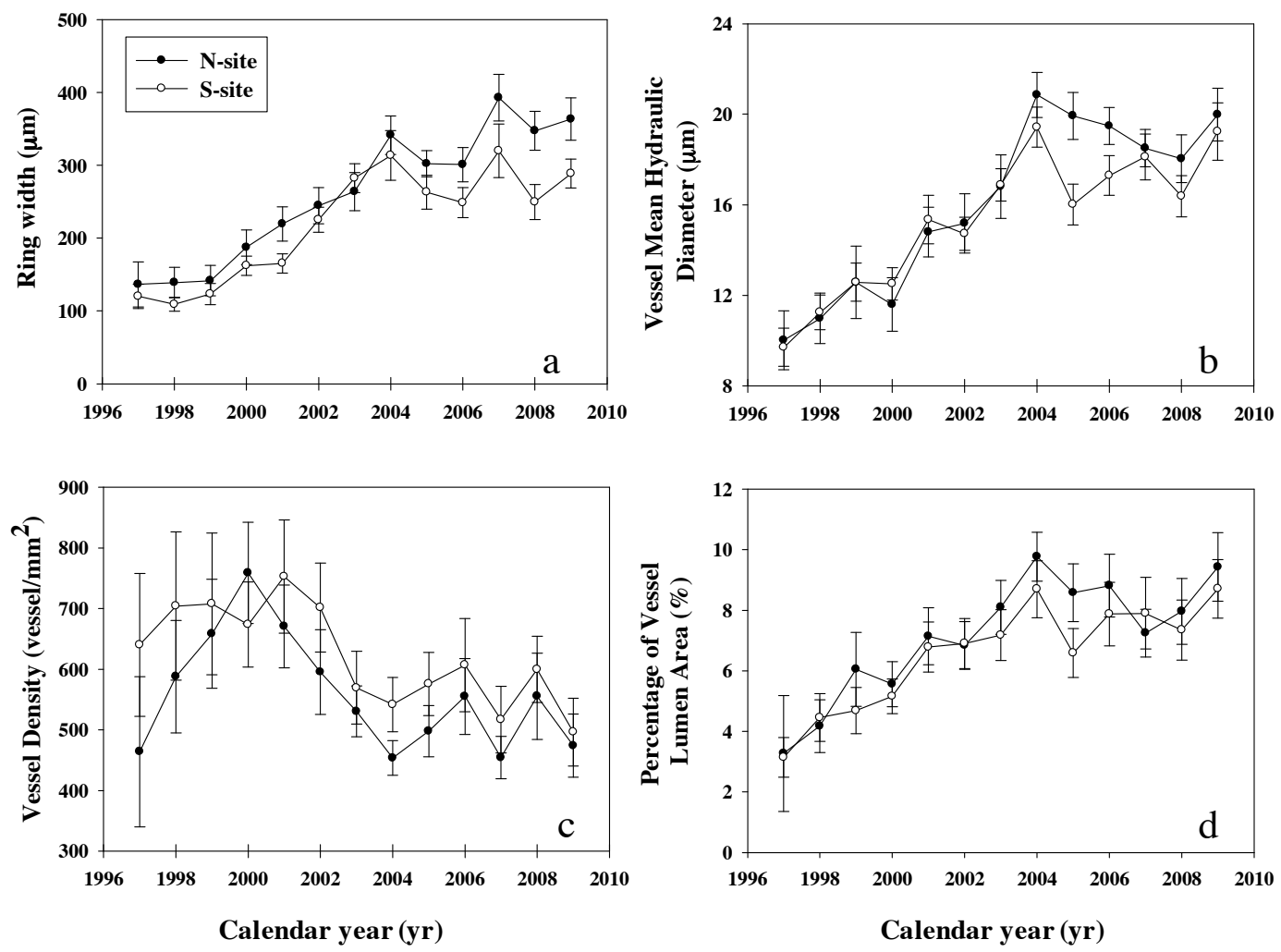

Fig. 3 Values of ring width (a), mean hydraulic diameter (b), vessel density (c), and percentage of vessel lumen area (d) of Linum at the northern and southern slope aspects of Villamayor, as grouped by calendar years. 

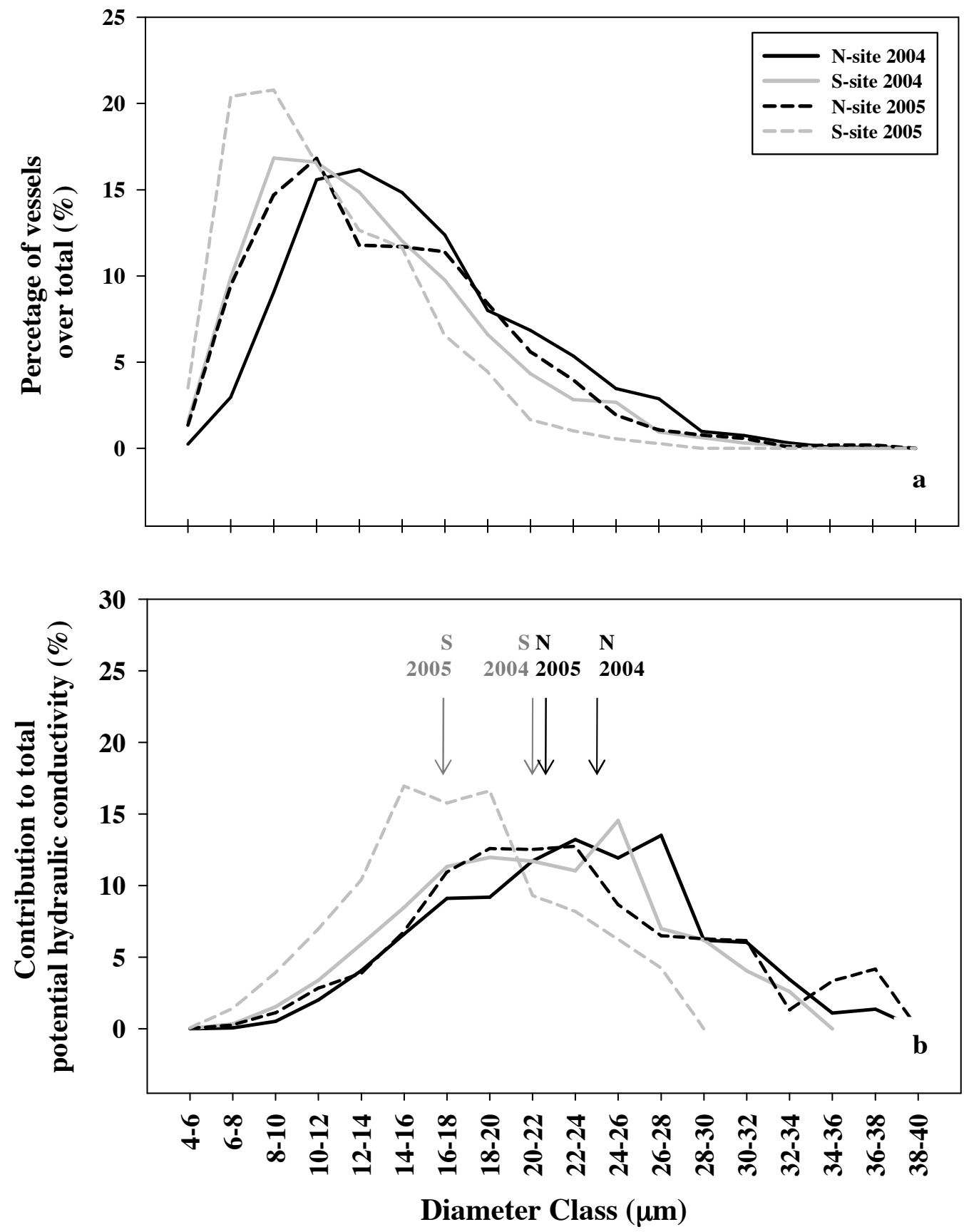

Fig. 4 Frequency distributions per $2 \mu \mathrm{m}$-diameter class of (a) percentage of vessels in each class over total, and (b) percentage of estimated vessel hydraulic conductivity over total, in the wet year 2004 and the dry year 2005 and at the northern and southern aspects of Villamayor (most individuals already at mature stage). Arrows indicate the diameter class at which the $50 \%$ of total estimated hydraulic conductivity is achieved at every considered aspect and year. 

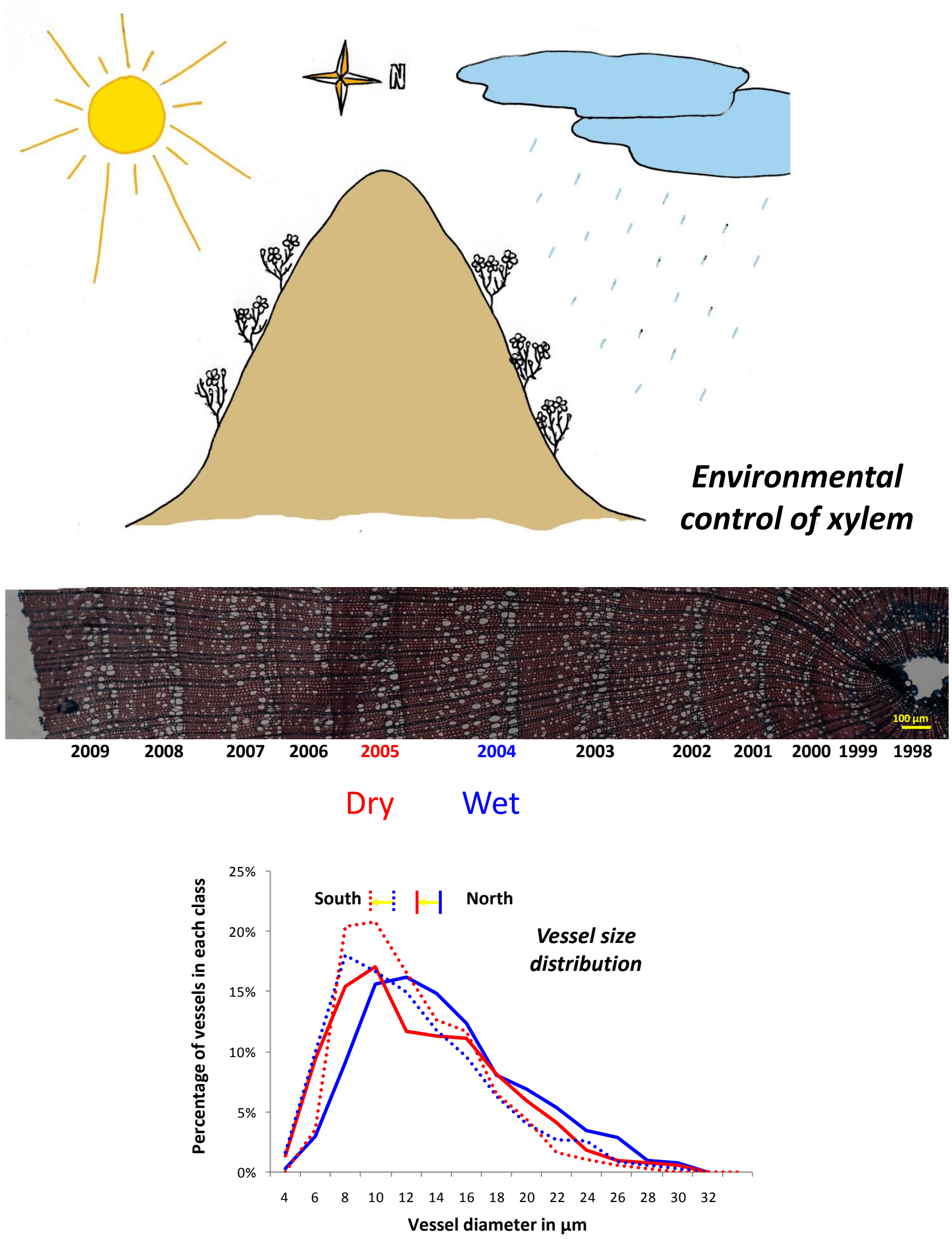


\section{Research highlights:}

- Ontogeny determined a shift towards a more efficient hydraulic configuration in the eighth year

- Plants at south-facing slopes produced narrower rings, smaller vessels and higher vessel density

- Safer anatomic features occurred in years with low rainfall at the beginning of the growing season

- Combining quantitative xylem anatomy along growth rings and GAMs solves ecological questions

- Ontogenetic and topographic effects cannot be neglected when dealing with plant distribution 


\section{Figure

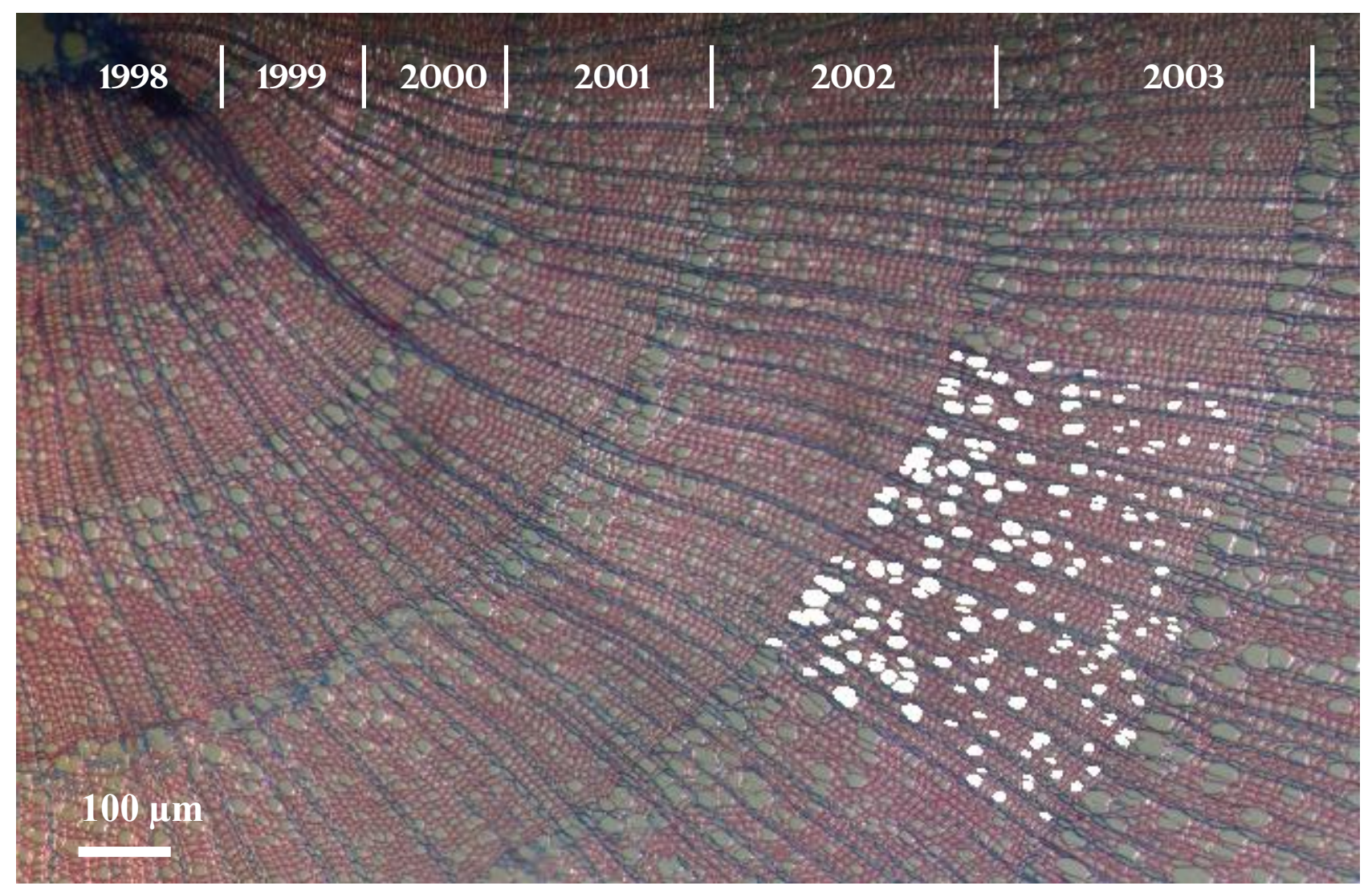



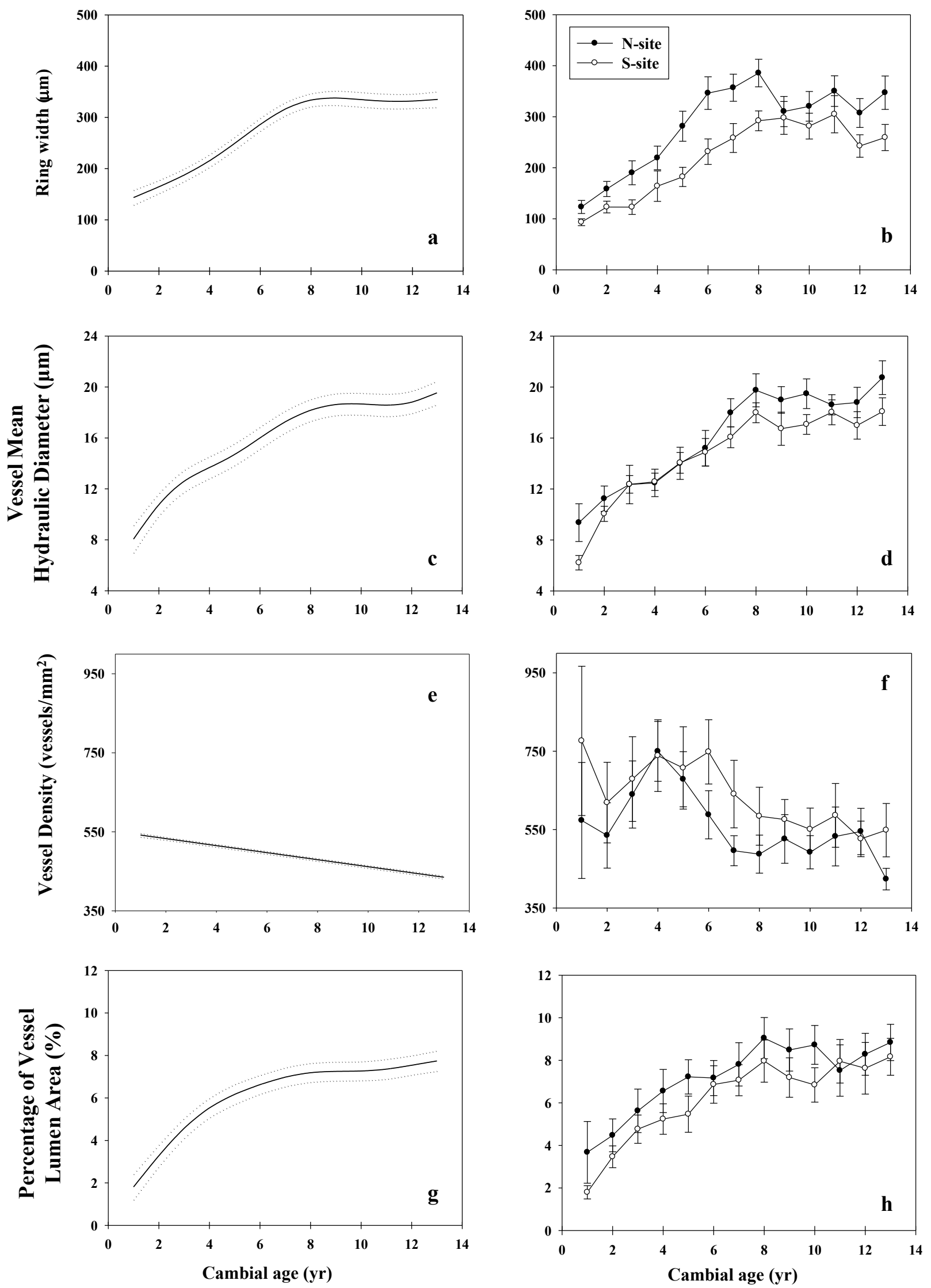

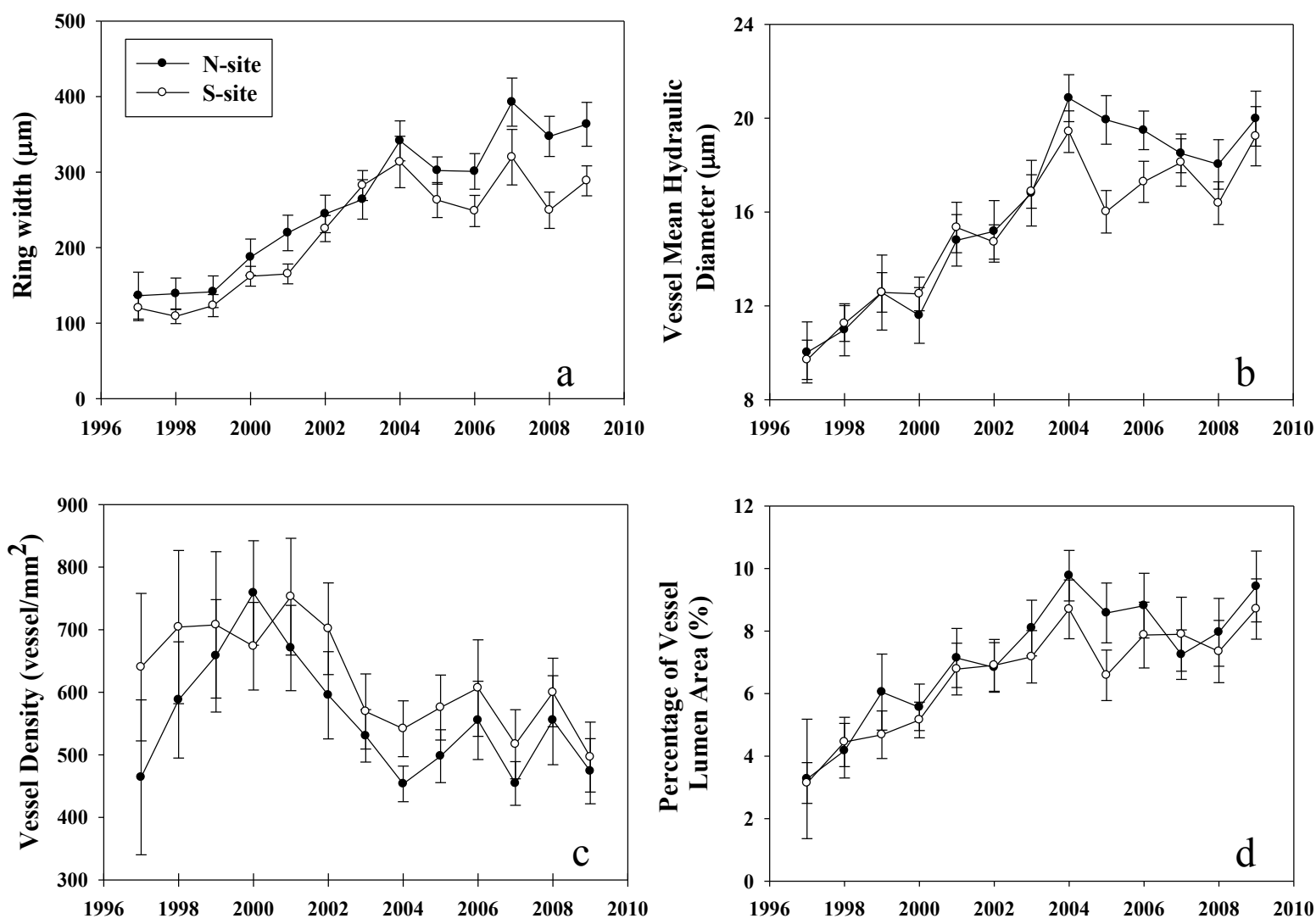

Calendar year (yr)

Calendar year (yr) 

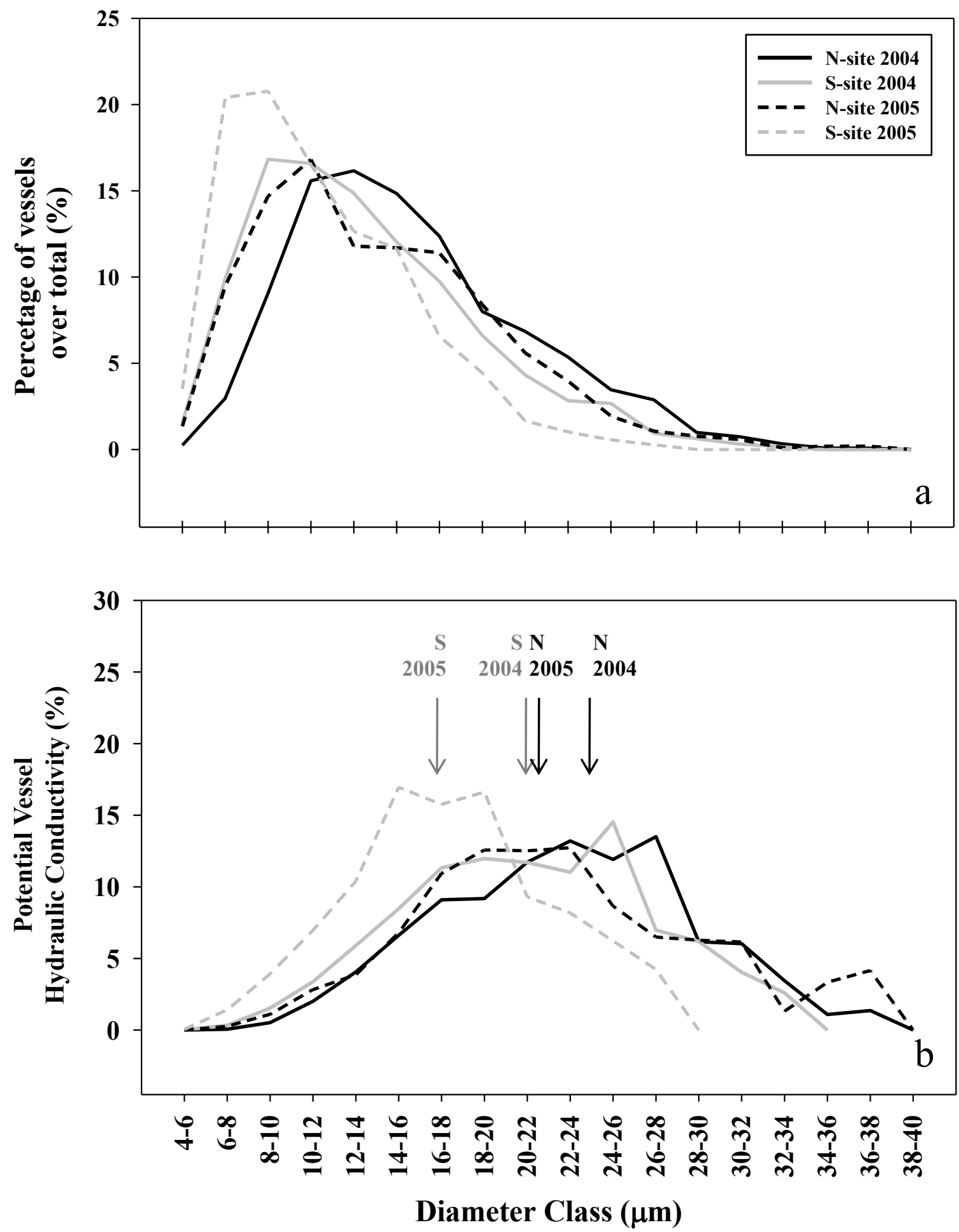